Pontifícia Universidade católica do Rio de Janeiro

\title{
Como o planejamento financeiro pessoal pode beneficiar o plano de aposentadoria de jovens brasileiros?
}

\section{André Gomes Araújo}

Trabalho de Conclusão de Curso

Centro de clências socials - CCS

Departamento de Administração

Graduação em Administração de Empresas 
Rio de Janeiro, Novembro de 2021. 
André Gomes Araújo

Como o planejamento financeiro pessoal pode beneficiar 0 plano de aposentadoria de jovens brasileiros?

Trabalho de Conclusão de Curso

Trabalho de Conclusão de Curso, apresentado ao programa de graduação em Administração da PUC-Rio como requisito parcial para a obtenção do título de graduação em Administração.

Orientador(a): Antonio Carlos Figueiredo

Rio de Janeiro

Novembro de 2021. 


\section{Agradecimentos}

Primeiramente, gostaria de agradecer a Deus pela sabedoria e toda força que me deu durante minha trajetória, que apenas eu e Ele sabemos o quão difícil foi.

Gostaria de agradecer minha família por todo amor, carinho, apoio e pelas oportunidades que me deram, sem eles não estaria aonde estou e não seria nem perto do que sou hoje.

Por último, mas não menos importantes, gostaria de agradecer meus amigos e colegas que fiz durante esse período incrível que tive, além de agradecer imensamente ao meu orientador Antonio Carlos Figueiredo, que me ajudou, me auxiliou e me guiou para o melhor caminho que poderia seguir em relação a meu trabalho.

\section{Resumo}

Gomes Araújo, André. "Como o planejamento financeiro pessoal pode beneficiar o plano de aposentadoria de jovens brasileiros?". Rio de Janeiro, 2021. Número de páginas 35p. Trabalho de Conclusão de Curso Departamento de Administração. Pontifícia Universidade Católica do Rio de Janeiro.

Este trabalho tem como objetivo mostrar o quanto um planejamento financeiro pessoal bem feito pode beneficiar brasileiros em situações financeiras complicadas e agregar ao plano de aposentadoria de jovens brasileiros, se feito desde cedo. Além disso, identificar quais os principais investimentos utilizados pelos jovens e deixar claro como investimentos principalmente em renda fixa, em ações de boas empresas e em fundos imobiliários podem contribuir a longo prazo para o plano de aposentadoria desses jovens. Os resultados evidenciaram que muitos ainda não adotam nenhum método para controlar o próprio orçamento ou planejar seus futuros gastos, sendo a grande maioria pelo fato de não possuírem conhecimento suficiente para realizarem investimentos por conta própria. 
Palavras- chave

Planejamento financeiro, aposentadoria, jovens brasileiros, instrumentos financeiros, renda fixa, ações, fundos imobiliários

\section{Abstract}

Gomes Araújo, André. "How can a personal financial planning benefit the retirement plan of young brazilians?". Rio de Janeiro, 2021. Número de páginas 35p. Trabalho de Conclusão de Curso - Departamento de Administração. Pontifícia Universidade Católica do Rio de Janeiro.

This article intends to show how a well done personal financial planning can benefit brazilians in complicated financial situations and add to the retirement of Brazilian youth, if done early on. Furthermore, identify the main investments used by young people and make it clear how investments in fixed income, in shares of good companies and, especially, in real estate funds can contribute in the long term to the retirement plan of these young people. The results showed that many still do not adopt any method to control their own budget or plan their future expenses, the vast majority due to the fact that they do not have enough knowledge to make investments on their own.

\section{Keywords}

Financial planning, retirement, young brazilians, financial instruments, fixed income, stocks, real estate funds 


\section{Sumário}

1 O tema e o problema de estudo

1.1. Introdução ao tema e ao problema do estudo

1.2. Objetivo do estudo

1.3. Objetivos intermediários do estudo

1.4. Delimitação e foco do estudo

1.5. Justificativa e relevância do estudo

2 Revisão de Literatura

2.1. Paradigmas da educação financeira no Brasil

2.2. Preparação para a aposentadoria: implantação e avaliação do programa Viva Mais!

2.3. Tipos e riscos de investimentos financeiros

2.4. Como identificar boas empresas e escolher boas ações

2.5. Opções de investimento em renda fixa

2.6. Fundos Imobiliários como uma forma de renda mensal

2.7. PGBL e VGBL

3 Métodos e procedimentos de coleta e de análise de dados do estudo

3.1. Etapas de coletas de dados

3.2. Fontes de informação selecionadas para coleta de dados no estudo

3.3. Procedimentos e instrumentos de coleta de dados utilizados no estudo

3.4. Formas de tratamento e análise dos dados coletados para o estudo

3.5. Limitações do estudo

4 Apresentação e análise dos resultados

4.1. Etapa única: Aplicação do questionário

4.1.1. Descrição do perfil dos respondentes 
4.1.2. Descrição e análise dos resultados do público alvo

4.1.3. Análise do público inserido no mercado financeiro

5 Conclusões

5.1. Sugestões e recomendações para novos estudos

6 Referências Bibliográficas

\section{Lista de figuras}

\section{Lista de Gráficos}

Gráfico 1 - Faixa etária dos respondentes 24

Gráfico 2 - Gênero dos respondentes 25

Gráfico 3 - Local em que residem os respondentes 26

Gráfico 4 - Nível de escolaridade dos respondentes 26

Gráfico 5 - Renda Mensal dos respondentes $\quad 27$

Gráfico 6 - Importância do planejamento financeiro pessoal 28

Gráfico 7 - Idade com que começou a guardar o próprio dinheiro 28

Gráfico 8 - Pretende fazer um plano de aposentadoria? 29

Gráfico 9 - Idade com que pretende se aposentar 29

Gráfico 10 - Investe seu próprio dinheiro? 30

Gráfico 11 - Investimentos financeiros dos respondentes 31

Gráfico 12 - Motivos para não investir hoje 31 


\section{O tema e o problema de estudo}

Esse capítulo volta-se à apresentação do tema que se pretende desenvolver e do problema de estudo.

Assim, apresenta-se o problema que suscitou a proposta de investigação e respectivos objetivos de pesquisa. Na sequência, são indicadas as suposições e as hipóteses do estudo e se informa a relevância e justificativa do estudo e a delimitação e foco do estudo.

\subsection{Introdução ao tema e ao problema do estudo}

Qualquer empresa que quer ser bem sucedida precisa ter um planejamento financeiro bem feito e organizado. No entanto, muitas vezes o planejamento financeiro pessoal do gestor, o jeito como ele se organiza e lida com suas finanças pode influenciar no futuro de sua organização. Mais que isso, pode afetar seu futuro como um todo, inclusive seu plano de aposentadoria.

Esta não é uma questão que afeta apenas empresários e donos de negócios, ela faz parte da vida de grande parte dos brasileiros, desde uma família com difíceis condições financeiras a outra melhor estruturada. De acordo com SEGUNDO FILHO (2003), os conhecimentos básicos de finanças pessoais não devem ficar restritos aos especialistas da área financeira. Qualquer pessoa, independentemente de sua atividade profissional, deve conhecer os princípios básicos necessários à administração de sua vida financeira.

Com o avanço da medicina e a crescente busca por estilos de vida mais saudáveis, é fato que o ser humano tem vivido cada vez mais. Em relação à aposentadoria, isso pode ser maravilhoso se a pessoa se planejar e se estiver bem preparada, no entanto pode ser um problema se ela não estiver, já que corre o risco de longevidade, ou seja, o risco dos recursos destinados para o pagamento da aposentadoria acabem antes do final de sua vida.

É uma questão que afeta tanto idosos como jovens, mas este estudo tem um foco maior neste último, principalmente por acreditar que quanto mais cedo se faz um planejamento, maior será a chance desse planejamento ter 
consequências grandiosas no futuro. $E$ isso ficou ainda mais difícil devido a Reforma da Previdência, que, além de fazer com que a aposentadoria por tempo de contribuição deixasse de existir, de maneira geral prejudicou os brasileiros em diversos aspectos, que, de acordo com INGRÁCIO (2019), agora vão se aposentar muito mais tarde e com benefícios muito piores.

O fato é que, saber como lidar com seu dinheiro, seja investindo ou guardando-o pensando mais a frente, um plano de aposentadoria por exemplo, é de suma importância e muitas pessoas no Brasil parecem não entender isso. Este fato é um dos principais motivos de vermos o número de famílias brasileiras com dívidas em atraso crescer cada vez mais com o passar do tempo. Segundo LISBOA (2021), no mês de agosto o percentual de famílias com dívidas em atraso continuou em alta e chegou a $72,9 \%$, um novo recorde mensal.

Segundo COTRIM (2020), 48\% dos brasileiros não controlam o próprio orçamento, ou seja, não se dedicam às próprias finanças e muito menos tem um planejamento financeiro. Segundo SOUZA (2018), em 2018 essa porcentagem era de $58 \%$. Isso mostra que os brasileiros estão percebendo cada vez mais a importância de controlar o próprio dinheiro, ainda mais nos tempos difíceis que temos passado, financeiramente falando. No entanto, ainda existe uma boa parte que não adota nenhum método para controlar o próprio orçamento, o que é uma situação no mínimo preocupante, e que poderia trazer muitos benefícios se feito da maneira correta.

Segundo relatório de SUTTO e SANTANA (2020), 90\% dos brasileiros com mais de 25 anos não guardam dinheiro pensando em aposentadoria. O país ficou em $43^{\circ}$ no ranking de 70 países, atrás de outros países emergentes como Índia e Rússia. Isso mostra um despreparo completo de grande parte dos brasileiros no momento de lidar com suas finanças, o que pode levar a cobranças e dívidas desnecessárias futuramente.

Resumindo, o conhecimento sobre finanças pessoais é obrigação para os indivíduos que vivem em um sistema capitalista. No mundo globalizado em que vivemos, vemos cada vez mais ofertas de consumo ao nosso redor, e se torna cada vez mais difícil resistir às tentações, ainda mais com a grande influência da mídia. Por isso, é vital que se tenha conhecimento das próprias finanças e realizar um planejamento e acompanhamento de seu orçamento visando uma melhoria de vida a curto, médio ou longo prazo. 
O tema do estudo diz respeito às finanças pessoais e aposentadoria, enquanto que o problema do estudo pode ser resumido na seguinte questão: "Como o planejamento financeiro pessoal pode beneficiar o plano de aposentadoria de jovens brasileiros?".

\subsection{Objetivo do estudo}

Esse estudo tem como objetivo central mostrar como o planejamento financeiro pessoal pode contribuir em situações financeiras complicadas e como pode ajudar no plano de aposentadoria de jovens brasileiros.

Mais que isso, entender mais da relevância deste planejamento ser feito desde cedo, já que pode antecipar problemas financeiros futuros e impedir que apareçam, além de entender um pouco mais dos motivos para quase metade dos brasileiros, de acordo com pesquisa de COTRIM (2020), não possuírem nenhum método para controlar o próprio orçamento.

Pretende-se, portanto, revelar a importância e os impactos positivos de entender e falar sobre finanças pessoais desde jovens, principalmente a respeito da realização de um plano de aposentadoria desde cedo.

\subsection{Objetivos intermediários do estudo}

Os objetivos intermediários para se atingir o objetivo final proposto pelo estudo são os seguintes:

- Descobrir com que idade os jovens pretendem se aposentar.

- Identificar com que idade, geralmente, as pessoas têm seu primeiro contato com planejamento financeiro pessoal.

- Identificar e analisar as principais formas de investimento utilizadas por jovens brasileiros.

\subsection{Delimitação e foco do estudo}

Esse estudo está preocupado em abordar a visão de jovens brasileiros, de no máximo 30 anos, a respeito de seu planejamento financeiro pessoal e seu plano de aposentadoria.

Tem como foco identificar os aspectos positivos trazidos por um planejamento e organização financeira para o plano de aposentadoria, além de analisar e buscar entender um pouco melhor os comportamentos dos afetados 
pelo assunto e o porquê de, em muitas situações, deixarem de organizar seu dinheiro. Se o motivo for exclusivamente a falta de conhecimento, pode-se concluir que deveria ser feito um maior engajamento nas escolas para crianças e jovens a respeito de finanças pessoais.

Além disso, busca entender melhor quais métodos são utilizados por esses jovens para controlar suas finanças, para quem os faz, além de planejamentos visando o futuro. Se, para os que não adotam nenhum método, é simplesmente desleixo e falta de interesse por parte deles, ou se existe algum impeditivo para tal planejamento ou para aprenderem mais a respeito do assunto.

\subsection{Justificativa e relevância do estudo}

É evidente que está se tornando cada vez mais importante conversar sobre educação financeira nos dias atuais. Com o passar do tempo, o dinheiro se tornou cada vez mais necessário na vida das pessoas, por isso é tão importante saber lidar e gerenciá-lo.

Além disso, é importante entender do assunto antes dos problemas financeiros aparecerem, já que às vezes é difícil reverter determinadas situações. Ainda mais em um país como o Brasil, onde as oscilações na economia geram desafios enormes no momento de realizar seu planejamento financeiro pessoal.

No entanto, muitas vezes as pessoas não aprendem cedo sobre planejamento financeiro nas escolas. A única alternativa de ensinamento dessas crianças e jovens passa a ser seus pais ou familiares, que em muitos casos não entendem ou não fazem seu próprio planejamento pessoal, criando alguém que não possuirá conhecimento algum de planejamento financeiro pessoal e que pode, futuramente, contrair inúmeras dívidas, como é o caso de centenas de famílias brasileiras.

Esse estudo foi feito justamente para sanar essa dúvida, se o brasileiro não tem tempo ou conhecimento para lidar com o próprio dinheiro ou se simplesmente não se importam em ter suas finanças organizadas e com um planejamento para o futuro. $\mathrm{O}$ indivíduo que não toma as medidas corretas a respeito desse assunto pode vir a se afundar em dívidas ainda jovem e problematizar sua aposentadoria indefinidamente. 
Além de entender o que se passa na cabeça de muitos a respeito de planejamento financeiro, dar respostas à essa questão que pode ser tão importante na vida de muitos é um dos assuntos principais desse estudo. Como uma forma de ajudar e levar a informação a quem precisa e tem a possibilidade de ser beneficiado e não aproveita, por qualquer motivo que seja. O importante é fazer as pessoas entenderem que se deve entender sobre, organizar, planejar, e ter controle sobre o próprio dinheiro para se ter um plano de aposentadoria bem feito. 


\section{Referencial teórico}

\subsection{Paradigmas da educação financeira no Brasil}

"Educação financeira sempre foi importante aos consumidores, para auxiliá-los a orçar e gerir a sua renda, a poupar e investir, e a evitar que se tornem vítimas de fraudes. No entanto, sua crescente relevância nos últimos anos vem ocorrendo em decorrência do desenvolvimento dos mercados financeiros, e das mudanças demográficas, econômicas e políticas." (OCDE, 2005).

Como dito anteriormente, parte dos brasileiros percebeu essa necessidade crescente de 2018 para cá. Com a crescente sofisticação do mercado financeiro, as famílias adquirem cada vez mais obrigações e correm cada vez mais risco ao tomar decisões financeiras. Por isso que tem se tornado cada vez mais importante que exista pelo menos uma pessoa na família que entenda a respeito de educação financeira, para evitar que passem por problemas desnecessários futuramente. De acordo com SAVOIA, SAITO e SANTANA (2007):

"A principal dificuldade do indivíduo é planejar adequadamente suas ações de longo prazo; é preciso poupar por conta própria para a aposentadoria, não mais provida integralmente pelo Estado. Também é necessário reavaliar as decisões sobre a compra de sua casa própria, e dos bens duráveis, bem como entender as novas modalidades de crédito e dominar a tecnologia disponível para a realização das transações financeiras básicas."

Nos últimos anos o governo foi incapaz de poupar e realizar investimentos propulsores de crescimento, que impulsionassem a economia do país. O consumo das famílias não consegue estimular os investimentos por si só, e é notável que o governo não exerce a função de capacitar a população adequadamente para a tomada de decisões no âmbito financeiro, o que dificulta cada vez mais o futuro dessas famílias.

"A população, despreparada para dimensionar o volume de comprometimento do seu orçamento, avança com ímpeto ao crédito fácil e, endividada, busca caminhos para restaurar o seu equilíbrio. O crescimento desorientado do crédito produz a inadimplência. A partir daí, os empréstimos são 
interrompidos e a economia reduz a sua atividade. Como consequência dessas ações, surge um círculo vicioso de expansão e retração do crescimento." SAVOIA, SAITO e SANTANA (2007).

Além disso, o fato de tantas famílias brasileiras sofrerem financeiramente devido à falta de informação afeta não só o futuro de suas vidas, mas da economia do país como um todo. Isso pode ser entendido melhor a partir da visão de BRAUSTEIN e WELCH (2002):

"Participantes informados ajudam a criar um mercado mais competitivo e eficiente. Consumidores conscientes demandam por produtos condizentes com suas necessidades financeiras de curto e longo prazo, exigindo que os provedores financeiros criem produtos com características que melhor correspondam a essas demandas."

O estudo ainda mostra programas ao redor do mundo cujo intuito é ensinar e informar a respeito de educação financeira. No entanto, no Brasil não foram encontrados trabalhos que consolidam as informações sobre educação financeira, então destacou-se as principais ações desenvolvidas no que tange ao processo de educação financeira.

Ainda segundo SAVOIA, SAITO e SANTANA (2007), o Ministério da Educação e Cultura (MEC) não demonstrava uma preocupação explícita com a inserção da educação financeira no ensino das escolas. No entanto, com o crescimento de sua importância, vem implementando o Programa Nacional de Educação Fiscal em conjunto com o Ministério da Fazenda, a Secretaria da Receita Federal, a Secretaria do Tesouro Nacional, e as secretarias da Fazenda e de Educação dos estados, com o intuito de capacitar os indivíduos no âmbito fiscal. São oferecidos cursos online e materiais sobre o assunto por meio da Escola de Administração Fazendária (Esaf).

O Banco Central do Brasil possui o Programa de Educação Financeira (PEF), responsável pela orientação da sociedade a respeito de assuntos econômicos, contribuindo para um melhor entendimento dos aspectos financeiros e da responsabilidade no planejamento das finanças pessoais. Algumas ações implementadas pelo Bacen foram a implementação do Projeto Museu-Escola, que envolve visitas monitoradas ao museu do Bacen, do Projeto Museu Vai à Escola, que é uma extensão do Projeto Museu-Escola, levando palestras e exposições às escolas do Distrito Federal e de regiões próximas e do Projeto $\mathrm{BC}$ e Universidade, composto por palestras mensais, ministradas por 
servidores do Bacen e direcionadas aos estudantes universitários, esclarecendo sua atuação e suas funções, todas voltadas à educação financeira.

"A educação financeira no Brasil se encontra em estágio de desenvolvimento inferior aos Estados Unidos e Reino Unido. No primeiro, o tema é adotado obrigatoriamente na grade de ensino de alguns estados, $72 \%$ dos bancos promovem programas de educação financeira, além de diversas organizações engajadas nesse processo. No Reino Unido, embora seja facultativa, há um forte envolvimento dos atores do processo, inclusive com a criação de um fundo, com o intuito de estimular a cultura de poupança. A explicação para essas diferenças entre o Brasil e os países citados está na compreensão de fatores históricos, culturais, bem como da responsabilidade das instituições no processo de educação financeira."

Por fim, SAVOIA, SAITO e SANTANA (2007) concluem:

"A educação financeira não foi agregada, de maneira oficial, nas grades curriculares e, nas universidades, não se constata uma ação efetiva e duradoura. Tal realidade reflete uma atuação ainda insuficiente do MEC, no que tange à inserção do tema em todos os níveis de ensino.

Assim como no ensino, também não se verifica o desenvolvimento de programas de educação financeira nos bancos brasileiros. As iniciativas existentes são escassas e não atendem às demandas dos seus clientes. A regulação da matéria pelo Banco Central pode ser uma alternativa para solucionar tal deficiência."

Tem se tornado cada vez mais evidente a situação preocupante no âmbito da educação financeira em que o Brasil se encontra e a urgência na inserção do tema em todas as esferas, ainda mais considerando a desequilibrada distribuição de renda de nosso país.

"Além de ser necessária uma coordenação maior de esforços e monitoramento das iniciativas do setor privado, o papel do setor público será de extrema importância para a propagação, fortalecimento e consolidação duradoura da educação financeira, sendo a participação das escolas e das universidades de grande relevância para o seu êxito." 


\subsection{Preparação para a aposentadoria: implantação e avaliação do programa Viva Mais!}

A aposentadoria tem se configurado como uma das transições relativas ao trabalho mais discutidas por diferentes segmentos da sociedade. Um dos focos investigados é o impacto da aposentadoria sobre a saúde mental dos aposentados e os fatores que facilitam ou dificultam o ajustamento a esta transição de vida.

De acordo com GARCÍA e RUIZ (2000), o ajustamento à aposentadoria é um fenômeno heterogêneo, com aumento na satisfação com a vida para uns, diminuição para outros e até mesmo estabilidade na satisfação com a vida entre aposentados. Algumas condições podem afetar o indivíduo negativamente com relação à adaptação à aposentadoria, como por exemplo: possuir filhos dependentes financeiramente, perder o parceiro durante a transição, aposentar-se mais cedo do que o esperado ou por problemas de saúde. Por outro lado, outras condições podem afetar o indivíduo positivamente, como por exemplo: ter saúde física e mental, aposentar-se por decisão própria, usufruir de bom status financeiro, engajar-se em lazer e trabalho formal ou voluntário, ter planejado a aposentadoria ou aposentar-se para fazer outras atividades.

De acordo com estudo feito por DUARTE e MELO-SILVA (2009), no setor privado foram encontrados relatos de experiências de angústia e ansiedade no período pré-aposentadoria e frustração e decepção com os proventos pós-aposentadoria, o que indicou que a escassez de recursos financeiros e informativos representa uma fonte de sofrimento para o grupo analisado

Já um estudo feito por OLIVEIRA, TORRES e ALBUQUERQUE (2009) envolvendo homens aposentados de cargos públicos apontou que os preditores de bem estar pós-aposentadoria estão relacionados ao planejamento da mesma, à satisfação com a saúde, às relações sociais e à mobilidade.

De acordo com ADAMS e RAU, "os programas de preparação para a aposentadoria devem auxiliar os participantes a encontrar respostas para as perguntas: 'O que vou fazer? Como vou sustentar isto? Com quem vou partilhar isto? Onde vou viver?". Neste sentido, é discutido que estes programas (PPAs) devem ser mais abrangentes e cobrir áreas como a ocupação, finanças, moradia, saúde, relações sociais e afetivas, além de aspectos legais da aposentadoria. 
Segundo FRANÇA e CARNEIRO (2009), três etapas principais integram a avaliação dos Programas de Preparação para a Aposentadoria. São elas:

- avaliações prévias ao programa para levantamento de necessidades e sensibilização de gestores

- avaliação de processo feita no decorrer do programa para monitoramento dos êxitos e dificuldades em sua condução

- avaliação de resultados para identificação das mudanças produzidas pela intervenção sobre os participantes.

Mesmo com um progresso significativo em estudos e publicações nacionais quanto às diretrizes para a implementação dos PPAs, ainda são poucas as empresas brasileiras que oferecem estes programas como parte de suas ações para promoção de saúde do trabalhador.

Dada a relevância social do tema, a Universidade de Brasília se engajou na criação de um programa de preparo para a aposentadoria para seus servidores, chamado Viva Mais!.

O principal objetivo do Programa Viva Mais! é promover o bem-estar, a saúde e a qualidade de vida dos trabalhadores da Universidade de Brasília. Seus objetivos finais são diminuir o surgimento de dificuldades emocionais nos anos que antecedem e sucedem a aposentadoria, como estresse e depressão por exemplo, e melhorar a qualidade de vida destes trabalhadores.

Para a implantação do Viva Mais! foi desenvolvido um modelo lógico a fim de melhorar a consistência global e a gerenciabilidade do programa. Todas as atividades presentes neste modelo são fundamentais para se alcançar os objetivos do programa.

De acordo com CASSIOLATO e GUERESI (2010), os principais elementos do modelo lógico são:

- os insumos, como os recursos humanos, organizacionais, financeiros e políticos;

- as atividades, que constituem os processos, que combinados com os insumos, produzem bens e serviços;

- os produtos, que são os bens ou serviços resultantes do processo de produção de uma atividade;

- os resultados, que correspondem às mudanças e benefícios associados à implementação das atividades do programa; 
- os fatores de contexto, que são as variáveis-chave, fora do controle da gestão do programa, que podem criar condições favoráveis ou desfavoráveis ao desempenho do programa.

A respeito da Avaliação de Necessidades, os instrumentos utilizados para sua realização foram um roteiro de entrevista semiestruturada para aposentados, composto por cinco questões abertas e um roteiro para grupo focal com servidores aposentados, também com cinco questões abertas.

"As questões das entrevistas e grupo focal abordavam as características do processo de transição para aposentadoria, as vivências positivas e negativas, as estratégias de enfrentamento adotadas após a aposentadoria e sugestões para trabalhadores que estejam em preparo para a aposentadoria."

Os resultados sugeriram um suporte intensivo da instituição na preparação de seus trabalhadores para esta etapa da vida, o que revela a urgência da implantação do programa. Em consequência, foram discutidas as implicações dos resultados para o conteúdo do grupo psicoeducativo, com a proposta de intervenções relacionadas ao autocuidado à saúde, educação financeira, redes sociais e orientação profissional.

Já a etapa de Avaliação de Processo compreendia dados coletados a partir da observação direta de comportamentos emitidos pelos participantes nas interações entre eles e entre os facilitadores durante as sessões. $O$ objetivo desta etapa era monitorar a qualidade de cada sessão da intervenção, a partir de certos critérios, sendo eles: verbalizações de prática, satisfação e integridade ou fidelidade.

A última etapa, Avaliação de Resultados, foi realizada dois meses após o término da intervenção, onde os participantes foram entrevistados individualmente por membros da equipe e questionados sobre o que mais e menos gostaram no decorrer de suas participações no programa Viva Mais!.

A respeito do que menos gostaram destacou-se:

- Duração - "Achei muito curto, poderia haver mais encontros";

- Conteúdo - "Considero que o programa deveria ter palestras sobre atividades físicas, independência [capacidade de viajar sozinha], dar mais opções para observar a aposentadoria como algo positivo";

- Ampliação da divulgação e captação dos participantes - "Levar o conhecimento às pessoas que estão próximas a se aposentar..."; 
- Assiduidade dos participantes - "Só achei que poderia ser mais cobrada a assiduidade das pessoas"

A respeito do que mais gostaram destacou-se:

- Técnicas utilizadas - "Gostei muito do desenho do corpo e do círculo das redes sociais";

- Trabalho em grupo - ". . . o trabalho em grupo é bom pra ver que todos têm seus problemas";

- Estrutura do programa - "Pra mim tudo foi muito bom porque a gente já fica com aquilo (conteúdo, forma de agir) na mente. Eu senti muita diferença depois do PPA"

- aprendizado obtido por meio do programa - "Percebi a importância dos relacionamentos com amigos e pessoas que estão mais distantes"

- participar da família - Participar com a minha esposa . . ."

- receber feedback dos terapeutas - "Gostei de estar com os terapeutas. Gostei muito das terapeutas darem feedback para cada um de nós"

Os relatos dos participantes coletados no decorrer e ao final do programa indicaram que a intervenção foi bem-sucedida no que diz respeito a seus objetivos. Todos os entrevistados relataram ganhos após participarem do Viva Mais! e manifestaram sua satisfação com os resultados, mesmo alguns apontando diferentes pontos negativos.

A partir do feedback e das sugestões dadas pelos participantes ao longo do programa, algumas medidas podem ser tomadas para aprimoramento do programa. Subsídios importantes foram fornecidos pelos participantes em termos de perspectivas futuras para as próximas intervenções do Viva Mais!, como por exemplo a insatisfação com a carga horária do programa.

Tal como proposto por FRANÇA e CARNEIRO (2009), acredita-se que para acompanhar cada participante ao longo do processo de entrada nesta nova fase da vida, deve-se acompanhar tais participantes por três anos após a aposentadoria. Isto também permitiria verificar o impacto do programa na saúde após a aposentadoria e avaliar se as metas a médio e longo prazo definidas pelo modelo lógico foram alcançadas. 


\subsection{Tipos e riscos de investimentos financeiros}

Existem diferentes tipos de investimentos financeiros que, dependendo do perfil da pessoa como investidor, podem agradar mais a uns que a outros. Existem duas classificações mais abrangentes onde os investimentos se encaixam: a renda fixa, onde os rendimentos são conhecidos desde o início da aplicação e a renda variável, onde os rendimentos são incertos.

Alguns exemplos de investimentos em renda fixa, segundo DICIONÁRIO FINANCEIRO (2019), são: Caderneta de poupança, que pode ser feita em qualquer agência bancária; CDB (Certificado de Depósito Bancário) e RDB (Recibo de Depósito Bancário); LCI (Letra de Crédito Imobiliário) e LCA (Letra de Crédito do Agronegócio), que se aplicam da mesma maneira, com a diferença que em um o capital será destinado a fundos imobiliários e no outro a fundos do agronegócio; LC (Letra de Câmbio), que funciona como uma forma de empréstimo aos consumidores; Tesouro Direto, que nada mais é que uma forma de arrecadação de fundos praticada pelo governo; Fundos de investimento, que podem ser considerados de renda fixa quando se destinam a aplicações mais conservadoras; debêntures, que são uma forma das empresas arrecadarem fundos de seus investidores; e o COE (Certificado de Operações Estruturadas), que é um tipo de investimento financeiro que combina produtos de renda fixa com os de renda variável.

Os principais investimentos em renda variável, ainda de acordo com DICIONÁRIO FINANCEIRO (2019), são: Ações, onde o investidor adquire parte do capital de uma empresa e recebe parte do lucro do período; Fundos de ações, que nada mais é que uma forma simplificada de adquirir ações de diferentes empresas; Fundos multimercados, onde os investimentos são mais amplos e são formuladas diferentes estratégias para o rendimento do investidor pela corretora responsável; Fundos imobiliários, onde o capital investido é destinado ao mercado imobiliário e comercializado através de cotas pelos imóveis disponíveis no fundo; e Derivativos, onde existem diferentes produtos financeiros cujos rendimentos derivam de outros produtos.

No entanto, um dos fatores mais importantes, ao lado da rentabilidade e do prazo de retorno, a ser considerado pelos investidores na hora de escolher um tipo de investimento é o seu risco. O risco, segundo DICIONÁRIO FINANCEIRO (2017), é o grau de incerteza em relação à rentabilidade do investimento, ou seja, a chance do mesmo dar um retorno abaixo do esperado, de se perder tudo 
o que foi investido ou, em casos extremos, da perda ultrapassar o valor do investimento inicial. Dependendo do grau de risco que o investidor está disposto a correr, este se encaixa em uma dessas três categorias: conservador, que é o menos disposto a correr riscos; moderado, que busca um equilíbrio maior entre risco e rentabilidade; e agressivo, que está disposto a fazer apostas mais arriscadas em busca de retornos maiores.

Por razões óbvias, os investimentos financeiros de renda fixa oferecem menos risco ao investidor do que os de renda variável, já que no primeiro já se sabe o rendimento desde o início da aplicação, e os investimentos em renda variável estão sujeitos a fatores externos, tornando seus ganhos mais incertos.

\subsection{Como identificar boas empresas e escolher boas ações}

Segundo WOLWACZ (2019), a principal diferença entre um investidor e um trader é a forma como olham pro mercado. Para o trader, a ação é uma ficha negociável na qual ele quer comprar barato e vender caro, sem nenhum apego com a empresa. Já o investidor tem como objetivo comprar parte de algumas empresas que ele considere ótimas para que ele possa ver seu patrimônio crescer à medida que as empresas vão evoluindo e crescendo.

No entanto, identificar uma empresa que seria interessante ser sócio muitas vezes pode ser uma tarefa mais complicada do que parece. Para WOLWACZ (2019), é necessário, antes de tudo, identificar o setor em que a empresa atua e analisar se faz sentido se tornar sócio desta empresa de acordo com a economia mundial.

Feito isso, é necessária a análise de diversos indicadores financeiros da empresa, para se ter certeza de que a compra destas ações é algo vantajoso ao investidor. É importante que a empresa possua um Lucro Líquido consolidado, estável e crescente, assim como seu Patrimônio Líquido, já que não é interessante ser sócio de uma empresa que está diminuindo de tamanho ou liquidando os seus bens para quitar dívidas. Além disso, é importante analisar o nível de endividamento da empresa e é aconselhável que este esteja caindo. No entanto, nem sempre uma dívida é totalmente ruim, esta pode ajudar a empresa a aumentar seu market share ou seu lucro líquido nos próximos balanços. $O$ aumento do nível da dívida será definitivamente ruim quando o lucro e patrimônio líquido da empresa estiverem caindo, fazendo a empresa ficar cada 
vez mais endividada. Outro indicador importante de ser analisado é o lucro por ação, e, por razões óbvias, quanto maior melhor. Patrimônios Líquidos com valor abaixo de 10 são considerados fantásticos, e o fato deste começar a subir significa que o preço da ação da empresa está subindo muito em relação ao Lucro Líquido gerado por ação, ou seja, a ação estaria muito cara, muito acima do que a empresa consegue produzir em termos de Lucro Líquido. É crucial analisar também a rentabilidade sobre o Patrimônio Líquido (ROE), que indica quanto a empresa consegue produzir em cima de seu Patrimônio Líquido e sua facilidade de conseguir crédito.

A análise de todos estes indicadores é de suma importância no momento de se tornar sócio de qualquer empresa. São eles que demonstram a real situação da organização em um contexto mais abrangente e como esta deve se comportar nos próximos períodos em atividade.

\subsection{Opções de investimento de renda fixa}

De acordo com WOLWACZ (2019), ao aplicar em renda fixa, o investidor está basicamente emprestando seu dinheiro para uma instituição, e esta se compromete a pagar juros pelo dinheiro investido. O tipo de instituição varia conforme o produto de renda fixa no qual estamos colocando nosso dinheiro, ou seja, se emprestássemos para o governo seria através do Tesouro Direto, se emprestássemos para um banco estaríamos investindo em um CDB (Certificado de Depósito Bancário), uma LCl (Letra de Crédito Imobiliário) ou LCA (Letra de Crédito Agronegócio) e se emprestássemos para uma empresa seria uma debênture, um CRI (Certificado de Recebíveis Imobiliários), CRA (Certificado de Recebíveis Agrícolas) ou LF (Letra Financeira).

O Tesouro Direto é um programa do Tesouro Nacional desenvolvido em parceria com a B3 para venda de títulos públicos federais para pessoas físicas de forma $100 \%$ online. Foi lançado em 2002 com o objetivo de democratizar o acesso aos títulos públicos, permitindo aplicações a partir de $R \$ 30,00$. O Tesouro Direto oferece títulos com diferentes tipos de rentabilidade, diferentes prazos de vencimento e diferentes fluxos de remuneração, tornando fácil encontrar o título mais indicado para alcançar os objetivos pessoais de cada investidor. O Tesouro Direto é acessível e apresenta muitas opções de investimento e, mesmo sendo a aplicação de menor risco do mercado, oferece uma boa rentabilidade e liquidez diária. 
O Certificado de Depósito Bancário é composto por títulos privados emitidos por uma instituição financeira. Ao emprestar dinheiro para o banco, o investidor recebe o retorno no vencimento na forma de juros, e tal remuneração pode ser pré-fixada, pós-fixada ou híbrida. Os CDBs sofrem incidência de Imposto de Renda e, para aplicações com menos de 30 dias, de Imposto sobre Operações Financeiras, além de ter a proteção do Fundo Garantidor de Crédito. As LCls e LCAs também são títulos privados emitidos por instituições financeiras. São semelhantes ao $\mathrm{CDB}$, na forma em que ocorrem suas remunerações e na proteção do FGC, no entanto, tem como objetivo financiar o setor imobiliário e agrícola, respectivamente, e são isentos de IR para pessoa física.

As debêntures são títulos de dívida de médio e longo prazo cujo intuito é captar empréstimos diretamente no mercado de capitais. Em caso de resgate com menos de 30 dias, há cobrança de IOF e esse título não possui cobertura do FGC, com exceção das debêntures incentivadas. As CRls e CRAs são títulos emitidos por empresas securitizadoras e, assim como as LCls e LCAs, têm o objetivo de financiar projetos do setor imobiliário e agrícola, respectivamente. Já as LFs são títulos de renda fixa emitidos por instituições financeiras com a finalidade de captar recursos de longo prazo, dado que têm vencimento superior a dois anos. No entanto, elas oferecem aos investidores melhor rentabilidade do que outras aplicações financeiras com liquidez diária ou com prazo inferior de vencimento, beneficiando tanto as instituições financeiras que necessitam captar recursos quanto os investidores que possuem um montante relevante para aplicações de longo prazo.

\subsection{Fundos Imobiliários com uma forma de renda mensal}

Ainda segundo WOLWACZ (2019), um fundo imobiliário é, basicamente, a reunião de investidores para comprar um imóvel que já está construído, comprar um terreno para incorporar, construir e vender ou comprar uma estrutura física, por exemplo, alugar esta estrutura e através do aluguel remunerar os investidores.

A partir daí, o investidor consegue comprar cotas desse fundo. É como se o indivíduo estivesse comprando um imóvel para alugar, no entanto não precisa pagar os $6 \%$ de corretagem que se paga ao comprar um imóvel, não precisa se preocupar muito com a vacância por serem diversas lojas e salas e, 
principalmente, o dinheiro cai todos os meses na conta do investidor, livre de imposto de renda. Existem diferentes tipos de fundos imobiliários. As principais tipologias existentes no Brasil são fundos de lojas comerciais, shoppings, galpões logísticos, hospitais, faculdades e de fundos.

$\mathrm{Na}$ maioria das vezes, ao invés de se ter uma carteira de dividendos é mais interessante investir em uma carteira de fundos imobiliários, já que este último geralmente tem maior rendimento mensal e, como dito anteriormente, já é isento de imposto de renda. Mesmo com suas cotas oscilantes, em certos momentos oscilando bastante, o fundo imobiliário é um investimento de renda variável que produz uma rentabilidade mensal relativamente constante.

No entanto, o investidor não terá sucesso simplesmente investindo em qualquer fundo imobiliário e esperando pelo melhor. Além da taxa de administração, performance e localização é preciso considerar alguns outros critérios do fundo. É importante analisar sua gestão, já que o gestor é responsável por investir o patrimônio do fundo, influenciando diretamente no desempenho do mesmo. Outro quesito a se avaliar é a liquidez do fundo, ou seja, a facilidade com que o investidor consegue resgatar o dinheiro aplicado, no intuito de saber se é fácil vender suas cotas ou não. Mais um ponto fundamental é o histórico do fundo, já que, mesmo não sendo garantia de rentabilidade no futuro, um fundo com um bom histórico é provável de continuar apresentando bons resultados.

Os investimentos em fundos imobiliários são de extrema importância para quem tem como foco sua aposentadoria, justamente por produzirem uma rentabilidade mensalmente. Mesmo variável, sua renda mensal passiva pode contribuir muito para a carteira e o plano de aposentadoria do investidor se tal investimento for feito desde cedo e da maneira correta.

\subsection{PGBL e VGBL}

As instituições financeiras oferecem dois tipos de planos de previdência privada para quem deseja poupar para a aposentadoria: os VGBL (Vida Gerador de Benefício Livre) e os PGBL (Plano Gerador de Benefício Livre). O PGBL é mais indicado para quem entrega a declaração completa do Imposto de Renda, enquanto que o VGBL pode ser a melhor opção para os demais poupadores e é especialmente indicado a quem está pensando em fazer seu planejamento sucessório. 
O PGBL e o VGBL foram estruturados como planos de acumulação, e por isso funcionam como planos de contribuição definida, ou seja, o benefício que a pessoa irá sacar depende diretamente daquilo que acumular durante o período em que investiu no plano. São planos bastantes semelhantes, cuja principal diferença é o tratamento fiscal. Tanto no PGBL como no VGBL o pagamento do imposto só acontece quando o benefício é resgatado, porém no caso do PGBL, durante a fase de acumulação, o indivíduo também pode abater o total contribuído ao plano do valor do seu imposto devido.

Uma grande vantagem do VGBL é que é possível determinar quem serão as pessoas que receberão o dinheiro que sobrar após sua morte e o recebimento desses recursos é extremamente rápido, costuma sair em menos de um mês. Já o PGBL é indicado para quem entrega a declaração completa e pode aproveitar benefícios fiscais, ou seja, a pessoa poderá pagar menos IR agora, colocar o dinheiro para render e só acertar as contas futuramente.

Cabe a cada indivíduo analisar o próprio perfil e identificar qual plano de previdência privada se encaixa melhor e se adequa a seus planos futuros. Os produtos de previdência geralmente não são muito agressivos nem arriscados, seu principal objetivo é preservar o patrimônio dos investidores e atingir uma rentabilidade interessante, de forma que o valor total acumulado até o final do plano seja o maior possível. 


\section{Métodos e procedimentos de coleta e de análise de dados do estudo}

Este capítulo pretende informar sobre as diversas decisões acerca da forma como este estudo foi realizado.

Está dividido em cinco seções que informam, respectivamente, sobre as etapas de coleta de dados do estudo realizado, sobre as fontes de informação selecionadas para coleta de informações neste estudo, sobre os procedimentos e instrumentos de coleta de dados realizados em cada etapa, com respectivas justificativas, sobre as formas escolhidas para tratar e analisar os dados coletados e, por fim, sobre as possíveis limitações do estudo.

\subsection{Etapas de coleta de dados}

A pesquisa, que tem como principais objetivos entender o porquê de grande parte dos jovens brasileiros não realizar seu próprio planejamento financeiro pessoal, e além disso, para o que estão mais inteirados no assunto, descobrir quais as principais formas de investimento utilizadas por eles, foi realizada através de um questionário online, por meio do Google Forms. De acordo com EVANS e MATHUR (2005), dentre as principais vantagens de se aplicar um questionário eletrônico destacam-se o baixo custo de implementação, a flexibilidade no momento de formulação das questões, a agilidade no momento de aplicação, controle e acompanhamento das respostas e a maior rapidez na tabulação dos resultados, por isso decidi fazer deste modo. Além disso, os respondentes ficam mais inclinados a responder o questionário já que é rápido e prático no momento de leitura e preenchimento. No entanto, de acordo com FELSON (2001), apesar da rapidez e baixo custo da utilização do questionário via Internet, a pesquisa com técnicas apenas on-line pode gerar resultados não representativos da população. Para HAIR (2005), é aconselhável uma amostra de no mínimo 100 casos para que se tenham resultados mais robustos, já que quanto maior o número de casos melhor. 
O questionário elaborado passou por uma fase de pré-aplicação, com uma amostra bastante reduzida, a fim de garantir que as perguntas fossem coerentes e de fácil entendimento. Só após a confirmação este foi compartilhado, contando com 13 perguntas no total, sendo 5 perguntas gerais e 8 perguntas relacionadas a finanças pessoais.

\subsection{Fontes de informação selecionadas para coleta de dados no estudo}

Como dito anteriormente, o questionário tinha como foco jovens brasileiros entre 18 e 29 anos de idade, no intuito de entender um pouco melhor como o planejamento financeiro está presente na vida de cada um.

O questionário foi distribuído para amigos, conhecidos e grupos nas redes sociais com público relevante ao alvo, com um pequeno texto contextualizando o assunto. A coleta de dados gerou 126 questionários respondidos, sendo 12 destes desconsiderados por terem sido respondidos por brasileiros com idade igual ou superior a 30 anos, restando 114 questionários considerados válidos. Buscou-se atingir pelo menos 100 respondentes no intuito de se obter resultados mais robustos e concretos. Os resultados gerados comprovam que existem muitos que ainda não controlam o próprio orçamento, quase metade dos respondentes.

Primeiramente, foram feitas perguntas mais genéricas no intuito de diferenciar os respondentes e obter algumas informações pessoais. Então, foram feitas perguntas relacionadas a finanças no intuito de identificar os respondentes que já estão inseridos no mercado financeiro, os investimentos mais utilizados por estes, identificar também quem não controla ou planeja seu próprio orçamento e os principais motivos para isso acontecer. Finalmente, foi deixado um espaço para os respondentes deixarem observações e comentários pertinentes, relacionados ao assunto, no intuito de tornar a pesquisa um pouco menos objetiva, abrindo espaço para explicações do porquê de certas respostas e anotações do dia a dia de cada um que possam agregar ao tema. 


\subsection{Procedimentos e instrumentos de coleta de dados utilizados no estudo}

Foi enviada uma mensagem aos participantes contextualizando e explicando a pesquisa, com o link do questionário para que pudessem preenchê-lo.

O questionário pode ser dividido em duas partes, contendo perguntas onde apenas uma resposta poderia ser marcada e outras onde múltiplas respostas eram possíveis. Na primeira, foram feitas perguntas gerais como nome, gênero, idade, escolaridade e em que local do Rio de Janeiro o respondente reside, se é que mora no Rio de Janeiro. Na segunda e última etapa, foram feitas perguntas relacionadas as finanças pessoais dos respondentes. Foi perguntado sua renda mensal, se têm o costume de investir o próprio dinheiro e se sim, em quais tipos de investimentos e se não, por quais motivos não o fazem.

Além disso, foi perguntado se os respondentes pretendem realizar um plano de aposentadoria futuramente, se já não possuírem um estabelecido. Então, para validar a importância da pesquisa feita, foi perguntado aos participantes o quão importante consideram o planejamento financeiro pessoal em suas vidas, variando de muito importante a desnecessário.

Pretendia-se com este questionário, após a análise das respostas, entender como e em que grau o planejamento financeiro está presente na vida de jovens brasileiros. O público-alvo da pesquisa eram jovens brasileiros, de no máximo 29 anos de idade. Com isso em mente, coletou-se informações do maior número de pessoas possível, a fim de entender também o porquê do planejamento financeiro pessoal não estar presente na vida de boa parte dos respondentes. Como o foco da pesquisa eram os jovens, buscou-se entender desde quando estes têm contato com planejamento financeiro, evidenciando a importância de se conhecer sobre o assunto desde cedo e, se não tiverem, o porquê de isso acontecer tão frequentemente. 


\subsection{Formas de tratamento e análise dos dados coletados para o estudo}

No questionário desenvolvido no Google Forms haviam perguntas objetivas, com apenas uma opção de resposta, perguntas condicionais e perguntas com mais de uma opção de resposta. Buscou-se com o questionário ter uma noção melhor de como e há quanto tempo o planejamento financeiro pessoal está presente na vida de jovens brasileiros e o porquê de terem pouco contato com o assunto, se for o caso.

Mesmo a grande maioria dos respondentes afirmando que pensam em realizar um plano de aposentadoria no futuro, ficou evidente que muitos ainda não possuem conhecimento suficiente para se organizar e planejar o próprio orçamento. Justamente devido a essa falta de informação, a realização de investimentos financeiros com foco no longo, ou até mesmo no curto prazo, se torna inviável, já que muitas vezes a renda mensal se torna insuficiente. Isso, em muitos casos, poderia ser resolvido ou minimamente melhorado se possuíssem qualquer forma de se planejar ou algum conhecimento para investir em opções pouco arriscadas, apenas para receberem uma renda mensal a mais.

Após a análise dos resultados, fez-se uma comparação das respostas obtidas, no intuito de se identificar as semelhanças e diferenças e assim, fazer as relações cabíveis.

\subsection{Limitações do Estudo}

Por ser um questionário objetivo, onde a maioria das questões são múltipla escolha com apenas uma opção de resposta, e virtual, devem ser analisadas as possíveis limitações metodológicas.

Pela falta de contato entre pesquisador e cada um dos respondentes, é possível que alguma questão tenha sido mal interpretada ou até mesmo não entendida. Para assegurar que o questionário estava de fácil entendimento e coerente com o assunto, foi realizada uma pré-aplicação do mesmo para um número bem menor de pessoas se comparada à amostra total, no intuito de sanar possíveis dúvidas de futuros respondentes. 
Pela falta de subjetividade do questionário, os respondentes poderiam ficar inclinados a assinalar uma determinada resposta, sem espaço para justificativas ou desenvolvimento do porquê de assinalar tal alternativa. No intuito de dar mais liberdade aos participantes da pesquisa no momento de preenchimento do questionário, foi adicionada uma opção livre a cada pergunta objetiva, caso o respondente sentisse que nenhuma das outras alternativas fosse a ideal. Além disso, foi criada, ao fim do questionário, uma lacuna para os respondentes deixarem comentários pertinentes ao assunto, como uma forma de criar mais engajamento e entender melhor o porquê de certas respostas. 


\section{Apresentação e análise dos resultados}

Este capítulo, organizado em 3 seções apresenta e discute os principais resultados alcançados, analisa e discute suas implicações e produz sugestões sobre o estudo previamente selecionado.

\subsection{Etapa única: Aplicação do questionário}

A partir da análise dos resultados obtidos, foi feita uma divisão em três seções: a descrição do perfil dos respondentes, a descrição e análise dos resultados do público alvo e a análise do público que está inserido no mercado financeiro.

\subsubsection{Descrição do perfil dos respondentes}

A maior parte dos respondentes possuía entre 18 e 23 anos, com um total de 66 pessoas, correspondendo a $52,4 \%$ do total de pessoas que participaram da pesquisa. Logo atrás ficaram os respondentes na faixa de 24 a 29 anos, com um total de 48 pessoas, correspondendo a $38,1 \%$ do total de respondentes. Em relação ao gênero, de 126 respondentes, 78 (61,9\%) eram mulheres e 48 $(38,1 \%)$ eram homens.

\section{Gráfico 1 - Faixa etária dos respondentes}

Idade:

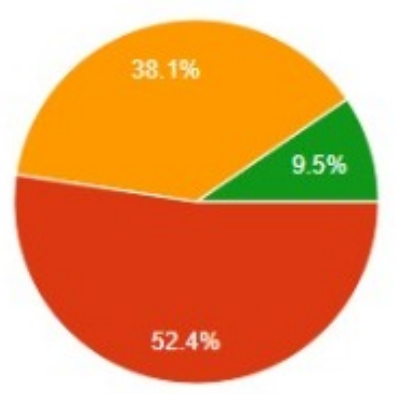


Fonte: Elaborado pelo autor através da pesquisa de campo, 2021

\section{Gráfico 2 - Gênero dos respondentes}

Gênero:

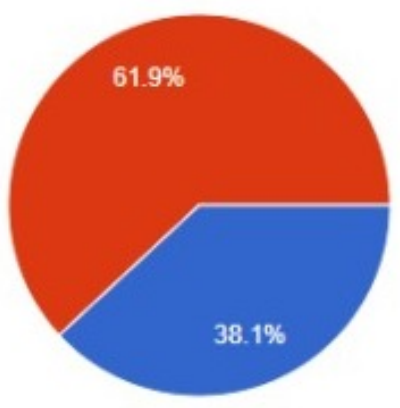

Fonte: Elaborado pelo autor através da pesquisa de campo, 2021

Outro fator que foi levado em consideração foi o local em que os respondentes residem no Rio de Janeiro, se de fato morarem na região. Boa parte dos respondentes reside na Zona Sul do Rio de Janeiro, com 62 pessoas correspondendo a $49,2 \%$ do total da amostra. Além disso, 17,5\% afirmaram residir na Zona Central, 14,3\% na Zona Oeste, 6,3\% na Zona Norte e 12,7\% (16 pessoas) não residem no Rio de Janeiro.

\section{Gráfico 3 - Local em que residem os respondentes}
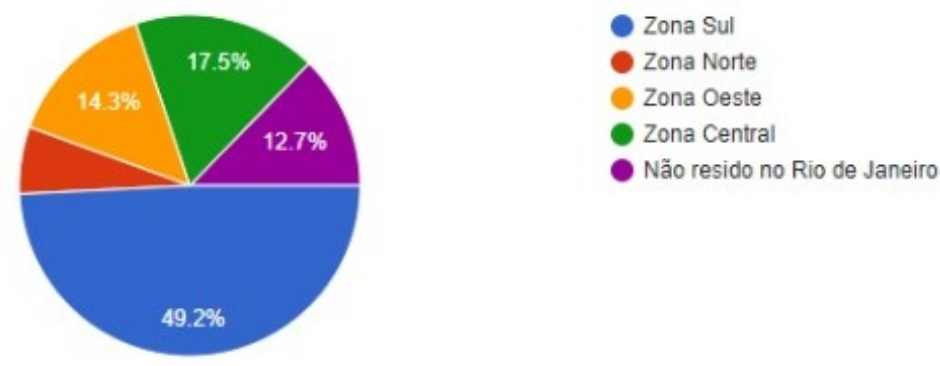

Fonte: Elaborado pelo autor através da pesquisa de campo, 2021 
Além disso, foi perguntado o nível de escolaridade dos respondentes, se já se formaram, se estavam cursando graduação ou se se formaram apenas no Ensino Médio. Por último, foi perguntada a renda mensal de cada respondente, levando em consideração todas as formas de receita do indivíduo. Um total de 54 pessoas alegou receber de 1 a 2 salários mínimos, correspondendo a 42,9\% dos respondentes, $14,3 \%$ alegaram receber de 2 a 3, 12,7\% alegaram receber de 3 a 4, 12,7\% também alegaram receber de 4 a 6, 9,5\% alegaram receber 6 ou mais salários mínimos e 10 pessoas, correspondendo a 7,9\% dos respondentes optaram por não responder a esta pergunta.

\section{Gráfico 4 - Nível de escolaridade dos respondentes}

Escolaridade:

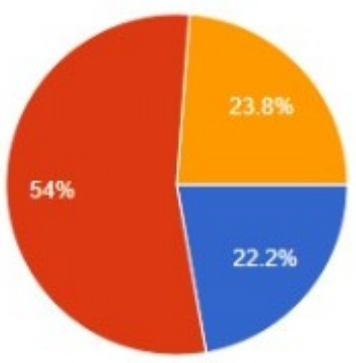

Ensino Médio Completo

- Ensino Superior Incompleto

- Ensino Superior Completo

Fonte: Elaborado pelo autor através da pesquisa de campo, 2021

\section{Gráfico 5 - Renda Mensal dos respondentes}

Renda Mensal:

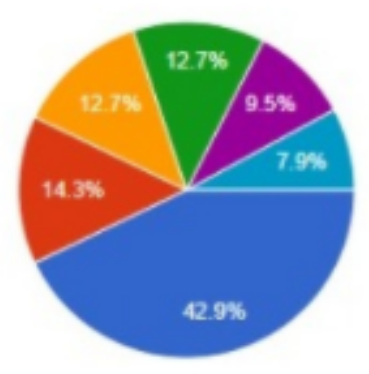

R\$ 1100,00 - R\$ 2200,00

R5 2200,00 - R5 3300,00

R\$ 3300,00 - R\$ 4400,00

R\$ 4400,00 - R\$ 6600,00

+ RS 6600,00

- Năo gostaria de responder

Fonte: Elaborado pelo autor através da pesquisa de campo, 2021 
No gráfico 5 fica evidente que a fatia de respondentes que recebem entre $\mathrm{R} \$ 1100,00$ e $\mathrm{R} \$ 2200,00$ (1 a 2 salários mínimos) é maioria. Isso pode ser explicado pelo fato de grande parte dos respondentes, aproximadamente $76,2 \%$ dos que responderam à pesquisa, estarem ou com seu Ensino Superior em andamento ou formados apenas no Ensino Médio.

\subsubsection{Descrição e análise dos resultados do público alvo}

Uma outra pergunta importante presente no questionário era em relação a opinião dos respondentes a respeito do assunto principal da pesquisa. Buscou-se identificar o grau de importância em que os respondentes atribuiriam seu próprio planejamento financeiro pessoal, com respostas variando de desnecessário a indispensável. Ficou claro o quão importante eles consideram seu planejamento financeiro pessoal, já que $47,6 \%$ dos respondentes classificaram como indispensável, 49,2\% classificaram como muito importante, apenas $3,2 \%$ dos respondentes classificaram como pouco importante e nenhum deles considera que seu planejamento financeiro pessoal seja algo desnecessário.

\section{Gráfico 6 - Importância do planejamento financeiro pessoal}

\section{Importância do planejamento financeiro pessoal em sua vida:}

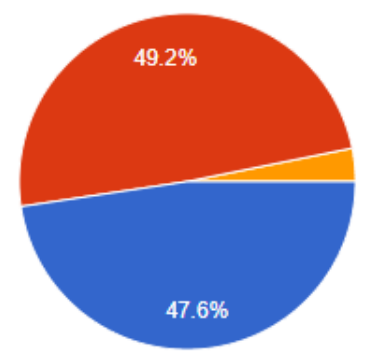

A partir disso foi perguntado com que faixa etária os respondentes começaram a guardar o próprio dinheiro. $O$ intuito da pergunta era identificar se os respondentes já possuem tal responsabilidade desde cedo ou se são inseridos no assunto tardiamente. 


\section{Gráfico 7 - Idade que começou a guardar o próprio dinheiro}

Com que idade começou a guardar o próprio dinheiro?

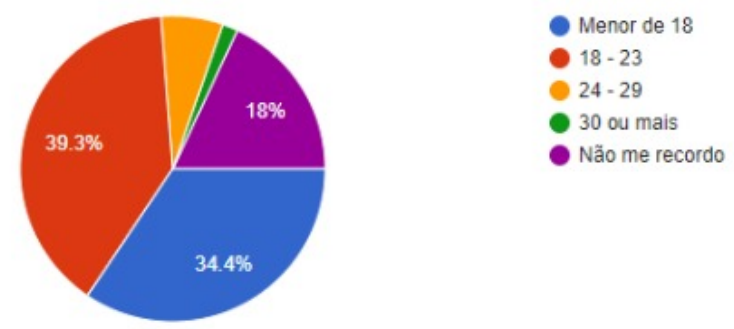

Fonte: Elaborado pelo autor através da pesquisa de campo, 2021

Apesar de boa parcela, aproximadamente $18 \%$, dos respondentes não se lembrar de quando começaram a se planejar e guardar o próprio dinheiro, vale destacar que a grande maioria dos que responderam à pergunta tiveram seu primeiro contato com menos de 24 anos. Com uma pequena vantagem, 39,3\% dos respondentes afirmaram ter seu primeiro contato entre 18 e 23 anos, logo atrás, 34,4\% dos respondentes afirmaram ter começado antes dos 18 anos e apenas $8,2 \%$ deles começaram a guardar seu dinheiro com 24 anos ou mais.

Então, foi perguntado se os respondentes pretendem fazer um plano de aposentadoria futuramente e com qual idade pretendem se aposentar. A maioria esmagadora, $88,5 \%$ dos respondentes, afirmaram que possuem um plano de aposentadoria em seus planos futuros, enquanto que $8,2 \%$ afirmaram que não pretendem realizar e apenas 3,3\% dos respondentes afirmaram já possuir um plano de aposentadoria. 


\section{Gráfico 8 - Pretende fazer um plano de aposentadoria?}

Pretende fazer um plano de aposentadoria?

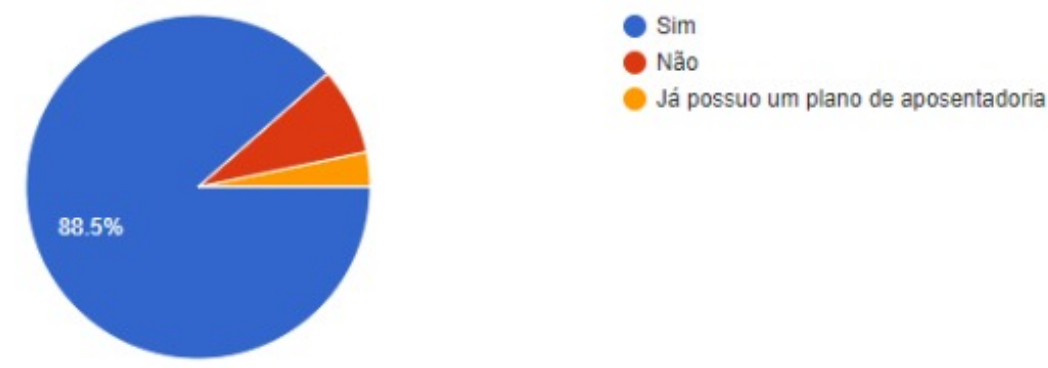

Fonte: Elaborado pelo autor através da pesquisa de campo, 2021

\section{Gráfico 9 - Idade com que pretende se aposentar}

Pretende se aposentar com que idade?

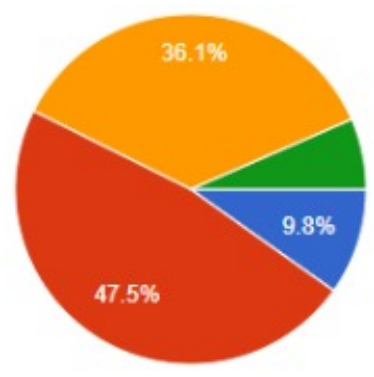

$40-50$

$50-60$

Mais de 60

Não penso em aposentadoria

Fonte: Elaborado pelo autor através da pesquisa de campo, 2021

Com relação a idade, como pode ser visto no gráfico 9 , apenas $9,8 \%$ pretendem se aposentar entre 40 e 50 anos, $47,5 \%$ dos respondentes pretendem se aposentar entre 50 e 60 anos e $36,1 \%$ pretendem se aposentar com mais de 60 anos de idade. O surpreendentemente é que 8 pessoas, aproximadamente $6,6 \%$ dos respondentes, afirmaram nem pensar em aposentadoria no momento, quanto mais investir com foco nela.

\subsubsection{Análise do público inserido no mercado financeiro}

Após estas perguntas, foi perguntado quem de fato se planeja e investe o próprio dinheiro. O resultado foi parecido com o esperado, já que 68 pessoas, 
correspondendo a $54 \%$ dos respondentes, responderam positivamente enquanto que 58 pessoas, os $46 \%$ restantes, responderam de maneira negativa.

\section{Gráfico 10 - Investe seu próprio dinheiro?}

Investe seu próprio dinheiro?

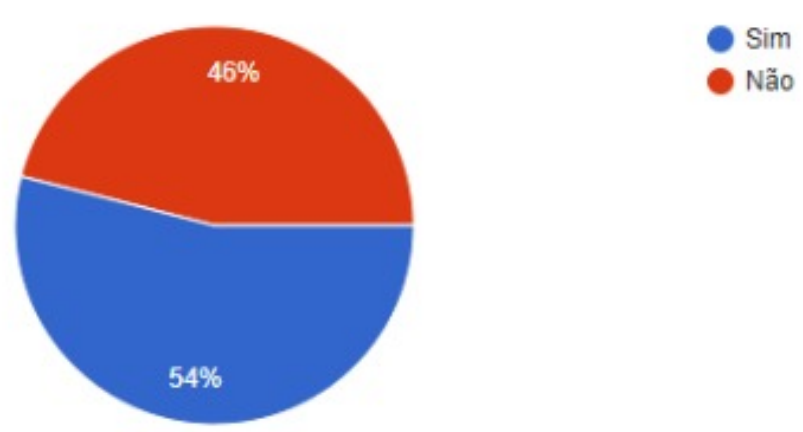

Fonte: Elaborado pelo autor através da pesquisa de campo, 2021

Importante ressaltar que mais da metade dos respondentes investem o próprio dinheiro de alguma forma, mas como dito anteriormente, ainda existem muitos que não adotam nenhum método, e entender mais dos motivos para isso acontecer se tornou um dos principais pontos da pesquisa.

A partir da divisão dos que investem seu próprio dinheiro e dos que não o fazem, foi perguntado em quais investimentos financeiros os respondentes que estão inseridos no mercado aplicam e, aos que não investem, qual seriam os motivos para tal. 


\section{Gráfico 11 - Investimentos financeiros dos respondentes}

Se sim, em quais:

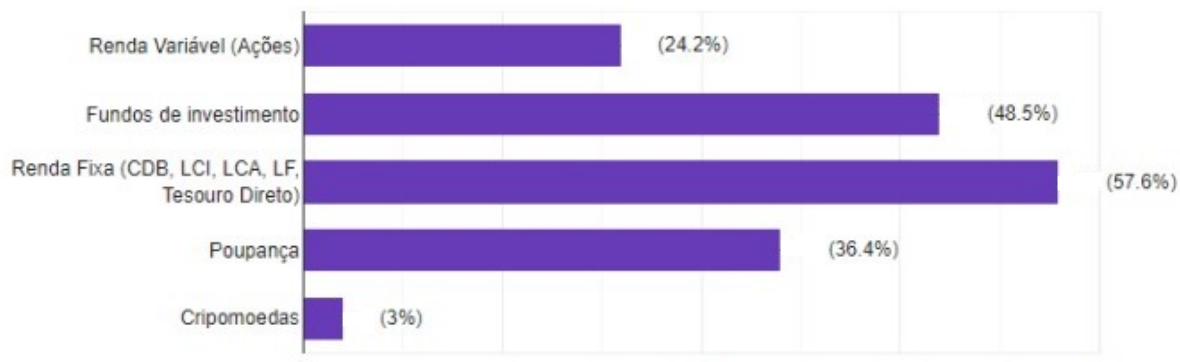

Fonte: Elaborado pelo autor através da pesquisa de campo, 2021

Como é possível observar no gráfico, o produto mais investido pelos respondentes é a renda fixa (CDB, LCI, LCA, LF, ou Tesouro Direto) com 57,6\% dos respondentes que de fato investem seu próprio dinheiro, logo atrás vem os fundos de investimento com $48,5 \%$, seguido da poupança com $36,4 \%$, da renda variável com $24,2 \%$ e por último as criptomoedas com apenas 2 votos.

\section{Gráfico 12 - Motivos para não investir hoje}

Se não, por qual motivo:

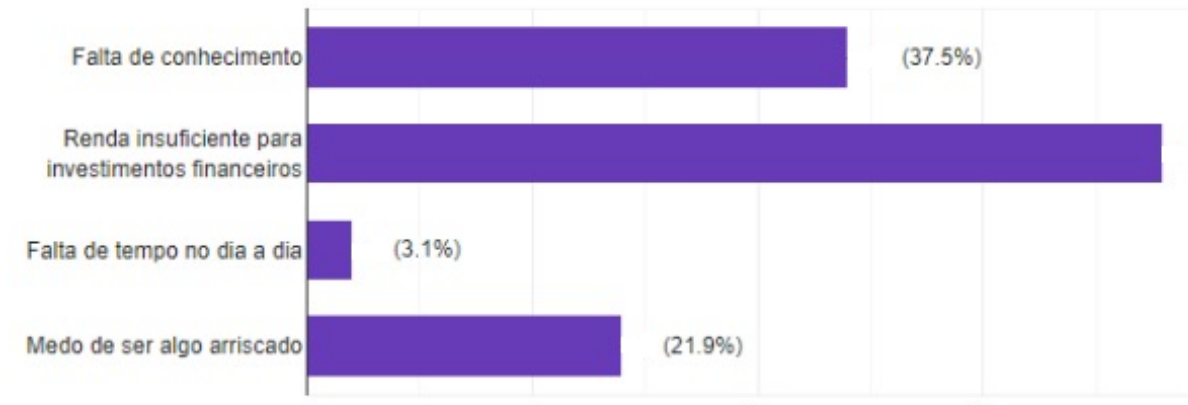

Fonte: Elaborado pelo autor através da pesquisa de campo, 2021

A maioria dos que não investem seu próprio dinheiro, $59,4 \%$ deles, afirmaram não o fazer por possuírem uma renda insuficiente para investimentos financeiros, o que pode ser explicado um pouco melhor pelo gráfico 5 , onde fica claro que a maioria dos respondentes ganha de 1 a 2 salários mínimos. Outros 
motivos importantes que devem ser destacados são a falta de conhecimento, assinalada por $37,5 \%$ dos que não investem e, atrelado a isso, o medo dos investimentos serem algo arriscado com $21,9 \%$ dos que não investem, já que, se a pessoa não entende do assunto, fica difícil identificar quais investimentos são mais seguros. Por último, apenas $3,1 \%$ dos que não investem alegaram falta de tempo no dia a dia para realizar investimentos financeiros. 


\section{Conclusões}

A respeito do questionário, o primeiro ponto importante a ser destacado é sobre a opinião dos respondentes em relação ao assunto. Como está explícito no Gráfico 6, 49,2\% dos respondentes classificaram o planejamento financeiro pessoal como muito importante e $47,6 \%$ como indispensável, restando apenas $3,2 \%$ dos respondentes que o classificaram como pouco importante e nenhum dos que participaram da pesquisa o classificou como desnecessário. Após isso, a grande maioria dos respondentes afirmou que pretende realizar um plano de aposentadoria e quase metade dos respondentes informou pretender se aposentar com idade entre 50 e 60 anos, o que é relativamente cedo para quem não se planeja de forma alguma nem investe o próprio orçamento. Isso se torna um pouco contraditório ao analisarmos, no Gráfico 10, a quantidade de respondentes que de fato se planejam e investem o próprio dinheiro, onde quase metade dos participantes, afirmaram que não o fazem.

Ficou claro que a grande maioria tem noção e entende da importância de realizar seu próprio planejamento financeiro e também pretendem fazer um plano de aposentadoria futuramente, no entanto muitos ainda não o fazem por diversos motivos, nem seguem o caminho que deveriam para ingressar no mercado. Isso é preocupante, já que mesmo sabendo de sua importância, os mesmos que não se planejam podem estar em situações financeiras difíceis futuramente, que poderiam ter sido revertidas ou nem apareceriam se tivessem o mínimo de organização desde cedo. Por isso é importante se organizar, planejar um plano de aposentadoria e se interessar pelo assunto o mais cedo possível, para evitar dívidas desnecessárias, controlar melhor os próprios gastos além de reduzi-los ao máximos e organizar melhor sua vida de maneira geral, já que se possui uma organização adequada do que fazer com o próprio dinheiro, as outras atividades tendem a fluir mais naturalmente.

Dentre os motivos para não investirem mais assinalados, estão a renda insuficiente para investimentos financeiros, o que pode ser entendido um pouco melhor ao analisarmos o Gráfico 5, já que grande parte dos respondentes afirmaram ter renda mensal de 1 a 2 salários mínimos. Outro motivo que deve 
ser destacado é a falta de conhecimento por parte dos respondentes, que foi ressaltado também em comentários feitos por alguns deles ao final do questionário: "Acho muito importante, mas não tenho o conhecimento que gostaria de ter para investir e fazer meu planejamento sozinha.". Isso está atrelado também a outro motivo bastante assinalado, que é o medo do investimento ser algo arriscado, já que se a pessoa não entende sobre o assunto, nem nunca realizou investimentos financeiros anteriormente, fica difícil identificar as melhores formas que encaixem com seu perfil investidor e os riscos trazidos com elas. Pela falta de conhecimento, a pessoa deixa de investir por medo de perder parte ou todo o dinheiro investido, já que não entende nem a respeito de investimentos de baixo risco. A respeito dos tipos de investimentos financeiros, os mais utilizados pelos respondentes, de acordo com o Gráfico 11, são renda fixa e fundos de investimento, com 57,6\% e 48,5\% respectivamente, e logo atrás vêm a poupança e renda variável, que também merecem destaque. Faz sentido a renda fixa estar no topo da lista por serem investimentos de menor risco, onde o investidor já tem noção da rentabilidade que aquele investimento irá gerar futuramente e também fica claro que muitos ainda consideram a poupança como um investimento positivo, porém existem outras opções de investimentos que são mais rentáveis e tão seguras quanto.

Um dos intuitos deste trabalho era identificar as diferentes opções de investimento utilizadas pelos respondentes e, além disso, destacar as mais interessantes caso o assunto seja plano de aposentadoria. A respeito de investimentos com renda fixa e renda variável, não existe uma resposta correta para se afirmar qual será o melhor para o futuro do investidor, tudo vai depender do perfil do mesmo e de sua capacidade de assumir riscos. Investindo em renda fixa o investidor correrá menos riscos de prejuízo, no entanto investindo em renda variável, se feito da maneira correta e cautelosamente, costuma-se ter um retorno bem maior.

Dito isso, uma das melhores opções pensando em aposentadoria são os fundos de investimento, que podem vir a ser muito importantes para o planejamento futuro do investidor, mais especificamente os fundos imobiliários. Mesmo gerando uma renda variável, estes possuem rentabilidade relativamente constante e, principalmente, esse dinheiro cai na conta do investidor mensalmente, já isento de imposto de renda. Além disso, o investidor não precisa se preocupar muito com a vacância, nem precisa pagar taxa de 
corretagem. Dentro dos próprios fundos imobiliários, o fundo de fundo pode ser uma boa oportunidade e pode se tornar uma grande vantagem ao investidor iniciante por conta da facilidade de investir no mesmo e, por ser um fundo que compra cotas de outros fundos imobiliários, possui uma grande diversificação de uma maneira relativamente simples. Além de diversificar instantaneamente sua carteira, o indivíduo, ao investir em fundos de fundos, tem acesso indireto a fundos melhores e exclusivos a investidores qualificados ou profissionais. Os fundos imobiliários podem se tornar uma renda extra passiva mensal, como se fosse de fato uma aposentadoria ou um aluguel.

Por fim, é importante passar a visão para as pessoas de que elas podem e devem se planejar, organizar o próprio orçamento e cortar, cada vez mais, gastos desnecessários no dia a dia. Dessa forma, é bem possível que conseguirão economizar parte de sua renda e investi-la de maneira correta e consciente, garantindo assim um futuro financeiramente estável e evitando dívidas futuras desnecessárias. 


\section{Referências Bibliográficas}

ABREU, S.; GIARDINI, S.; FRANÇA, C.; PEDRALHO, M.; SEIDL, J.; MOURA, N.; MOREIRA, R.; CONCEIÇÃO, A.; GUNTHER, I. Preparação para a aposentadoria: implantação e avaliação do programa viva mais! Scielo, Brasília, 27 mar. 2014. Disponível em: https://www.scielo.br/j/prc/a/BfgJcTxHDZknvJgCMHxSXFi/?lang=pt

ADAMS, G.; RAU, B. Putting Off Tomorrow to Do What You Want Today Planning for Retirement. Fev. 2011. Disponível em:

https://www.researchgate.net/publication/49855819 Putting Off Tomorrow to D o_What_You_Want_Today_Planning_for_Retirement

AYAN, J. CDB, LCI, LCA: entenda a sopa de letrinhas da renda fixa. 22 mar. 2020. Disponível em:

https://einvestidor.estadao.com.br/educacao-financeira/cdb-lci-lca-entenda-a-sop a-de-letrinhas-da-renda-fixa/

BRAUNSTEIN, S.; WELCH, C. Financial Literacy: An Overview of Practice, Research, and Policy. Nov. 2002. Disponível em:

https://www.federalreserve.gov/pubs/bulletin/2002/1102lead.pdf

CALEGARI, L. Brasileiro prefere investir em poupança, e acha que Bolsa é 'para ricos'. Uol, São Paulo, 14 dez. 2012. Disponível em:

https://economia.uol.com.br/noticias/redacao/2012/12/14/brasileiro-prefere-invest ir-em-poupanca-e-acha-que-bolsa-e-para-ricos.htm

CASSIOLATO, M.; GUERESI, S. Como elaborar Modelo Lógico: Roteiro para formular programas e organizar avaliação. Brasília, set. 2010. Disponível em: http://repositorio.ipea.gov.br/handle/11058/5810

COTRIM, C. $48 \%$ dos brasileiros não controlam o próprio orçamento, mostra pesquisa. Uol, São Paulo, 28 jan. 2020. Disponível em:

https://economia.uol.com.br/noticias/estadao-conteudo/2020/01/28/48-dos-brasil eiros-nao-controlam-o-proprio-orcamento-mostra-pesquisa-cndlspc.htm\#: : :text= At $\%$ C3\%A9\%2048\%25\%20dos $\% 20$ brasileiros $\% 20$ n $\%$ C3\%A3o,ao $\% 20 \mathrm{Cr} \% \mathrm{C} 3 \% \mathrm{~A}$ 9dito\%20(SPC\%20Brasil).

DUARTE, C.; MELO-SILVA, L. Expectativas diante da aposentadoria: um estudo de acompanhamento em momento de transição. São Paulo, jun. 2009. Disponível em:

http://pepsic.bvsalud.org/scielo.php?script=sci_arttext\&pid=S1679-339020 $\underline{09000100007}$ 
DUARTE, D. 5 investimentos em renda variável para você conhecer. Blog do Yubb, 27 jun. 2018. Disponível em:

https://blog.yubb.com.br/5-investimentos-em-renda-variavel/

DICIONÁRIO FINANCEIRO. Tipos de investimentos financeiros. 1 out. 2019.

Disponível em:

https://www.dicionariofinanceiro.com/tipos-de-investimentos/

DICIONÁRIO FINANCEIRO. O que é risco nos investimentos? 5 jul. 2017.

Disponível em:

https://www.dicionariofinanceiro.com/risco-nos-investimentos/

EVANS, J.; MATHUR, A. The Value of Online Surveys. Abr. 2005. Disponível em:

https://www.researchgate.net/publication/220146842 The Value of Online Surv eys

FELSON, L. Netting limitations. Marketing News. Chicago, 26 fev. 2001.

FRANÇA, L.; CARNEIRO, V. Programas de preparação para a aposentadoria: um estudo com trabalhadores mais velhos em Resende (RJ). 2009.

Disponível em:

https://www.scielo.br/j/rbgg/a/zhNmn87TmzdQkN4dyzjz7pk/abstract/?lang=pt

GARCÍA, A.; RUIZ, E. La preparación para la jubilación: Revisión de los factores psicológicos y sociales que inciden en un mejor ajuste emocional al final del desempeño laboral. 2000. Disponível em:

https://revistas.um.es/analesps/article/view/29981

HAIR, J. Análise Multivariada de Dados. 2005. Disponível em:

https://www.academia.edu/25729179/Livro_An\%C3\%A1lise_Multivariada de da dos Hair Anderson Tathan Black 5 Ed

INFOMONEY. PGBL: o plano de previdência que pode ser abatido no Imposto de Renda. 2019. Disponível em:

https://www.infomoney.com.br/quias/pgbl/

INFOMONEY. VGBL: garante aposentadoria e favorece herdeiros. 2019.

Disponível em:

https://www.infomoney.com.br/quias/vgbl/

INGRÁCIO, A. 4 Aposentadorias Antes e Depois da Reforma da Previdência. 29 abr. 2019. Disponível em:

https://ingracio.adv.br/aposentadoria-inss-reforma-da-previdencia/

INVESTIDOR SARDINHA. Fundos imobiliários para a aposentadoria - 5 Alternativas e como escolher. 4 mar. 2021. Disponível em: https://investidorsardinha.r7.com/opiniao/fundos-imobiliarios-para-a-aposentadori a/

LISBOA, V. CNC: percentual de famílias com dívidas chega a 72,9\%. Agência 
Brasil, Rio de Janeiro, 25 ago. 2021. Disponível em:

https://agenciabrasil.ebc.com.br/economia/noticia/2021-08/cnc-percentual-de-fa $\underline{\text { milias-com-dividas-chega-729 }}$

OCDE. Recommendation on Principles and Good Practices for Financial Education and Awareness. Jul. 2005. Disponível em: https://www.oecd.org/finance/financial-education/35108560.pdf

OLIVEIRA, C.; TORRES, A.; ALBUQUERQUE, E. Análise do bem estar psicossocial de aposentados de Goiânia. Dez. 2009. Disponível em: https://www.scielo.br/j/pe/a/NVPCgxY9Fzt4gdH8W8Jqchp/abstract/?lang=pt\#

REDAÇÃO ONZE. CDB ou LCl: qual o melhor título para investir? 26 jun. 2020. Disponível em:

https://www.onze.com.br/blog/cdb-ou-lci/

SAVOIA, J.; SAITO, A.; SANTANA, F. Paradigmas da educação financeira no Brasil. Dez. 2007. Disponível em: https://www.scielo.br/j/rap/a/XhqxBt4Cr9FLctVvzh8gLPb/?lang=pt

SEGUNDO FILHO, J. Finanças Pessoais: invista no seu futuro. Rio de Janeiro: Qualitymark, 2003.

SOUZA, L. Pesquisa revela que $58 \%$ dos brasileiros não se dedicam às próprias finanças. Agência Brasil, São Paulo, 28 mar. 2018. Disponível em: https://agenciabrasil.ebc.com.br/economia/noticia/2018-03/pesquisa-revela-que-5 8-dos-brasileiros-nao-se-dedicam-proprias-financas

SUTTO, G.; SANTANA, P. $\mathbf{9 0 \%}$ dos brasileiros não guardam dinheiro para a aposentadoria, diz estudo. Infomoney, São Paulo, 27 jun. 2020. Disponível em: https://www.infomoney.com.br/economia/90-dos-brasileiros-nao-guardam-dinheir o-para-a-aposentadoria-diz-estudo/

TESOURO DIRETO. Tudo o que você precisa saber sobre o Tesouro. Disponível em:

https://www.tesourodireto.com.br/conheca/conheca-o-tesouro-direto.htm

VASCONCELLOS, L.; GUEDES, L. E-Surveys: Vantagens e Limitações dos Questionários Eletrônicos via Internet no Contexto da Pesquisa Científica. 2007. Disponível em:

http://sistema.semead.com.br/10semead/sistema/resultado/trabalhosPDF/420.pd $\underline{f}$

VAZ, F.; PIRES, F. Carteira Fundos Imobiliários. Santander, 01 abr. 2021. Disponível em:

https://cms.santander.com.br/sites/WPS/documentos/arq-algo-mais-fundos-imobi liarios/21-04-12 170035 carteirafundosimobiliariossantandercorretoraabril21algo final.pdf

WOLWACZ, A. Como Investir em Renda Fixa? 25 ago. 2019. Disponível em: https://www.youtube.com/watch?v=xjeHebUwawk\&t=414s 
WOLWACZ, A. Fundos imobiliários: parte 1. 2020. Disponível em:

https://www.youtube.com/watch?v=N0a4fm 4UY0\&t=578s

WOLWACZ, A. Modelo Buffet de ganhar dinheiro! Comprar ações de boas empresas. 29 out. 2019. Disponível em:

https://www.youtube.com/watch?v=Med5fg9V3Ag

WOLWACZ, A. O meu tipo preferido de investimento hoje: Fundos Imobiliários. 2 set. 2020. Disponível em:

https://www.youtube.com/watch?v=xNdFHBF1xz4\&t=369s 